\title{
JURIDICAL STUDIES AGAINST DIVERSION IN CRIMINAL JUSTICE SYSTEM
}

\author{
Indah Setyowati \\ Sultan Agung Islamic University \\ indah@unissula.ac.id \\ Ida Musofiana \\ Sultan Agung Islamic University \\ ida.musofiana@unissula.ac.id
}

\begin{abstract}
The diversion provisions in the juvenile justice system law whether it has prevented children from the negative effects of the Criminal Justice System. The method of approach is the statutory approach and the comparative approach. Primary, secondary and tertiary legal materials obtained by the author will be analyzed using the method of systematic interpretation, namely interpretation by looking at the relationship between the rules in an interdependent law. Diversion is a settlement of child cases that are carried out outside formal justice with the aim of preventing children from stigmatizing children who are dealing with the law must be in accordance with the purpose of diversion in The Beijing Rules. Whereas in Indonesia, the diversion provisions in the Criminal Justice System Act of the Child are still included in the criminal justice system by giving stronger stigmatization to children who are in conflict with the law and so it is not in accordance with the purpose of diversion in The Beijing Rules. So the diversion provisions in the Child Criminal Justice System Law do not yet reflect the principle of child protection as mandated by the Child Protection Act and the Child Criminal Justice System Law.
\end{abstract}

Keywords : Children; Criminal justice system; Diversion.

\section{A. INTRODUCTION}

In Indonesia's positive law, protection of children's rights can be found in various laws and regulations, as stipulated in Presidential Decree No. 36 of 1990 on August 25, 1990, which is a ratification and convention of the UN Convention on the Rights of the Child (Convention of the rights of the child), Law No.4 of 1979 concerning Child Welfare, Law Number 23 of 2002 concerning Child Protection ${ }^{1}$ aw Number 39 of 1999 concerning Human

1 Nashriana, Legal protection for children in Indonesia, Raja grafindo Persada, Jakarta, 2011, P.13.
Rights, and Law Number 11 of 2012 concerning the Criminal Justice System for Children. Development of existing legal systems in Indonesia discussing children's problems who are dealing with the law with presenting the concept of diversion as an embodiment from restorative justice. ${ }^{2}$

In the era of globalization, the number of crimes committed by children, for example, is increasing every year, even though Indonesian regulations have governed it. Steve

2 Novi Edyanto, Restorative Justice To Resolve Cases Children Confronting the Law, Jurnal I/mu Kepolisian, Vol 11, Nomor 3, Dec 2017, P.40. 
Allen stated that more than 4,000 children in Indonesia are prosecuted each year for minor crimes such as theft. Not surprisingly, then, nine out of ten children were put in prison or detention centers. For example, Throughout 2000, recorded in police criminal statistics were more or less than 11,344 children suspected of being perpetrators of a crime. ${ }^{3}$

The principle of child protection is primarily about the principle of nondiscrimination which prioritizes the best interests of the child and the right to life, survival, and development so that it is necessary to respect the opinion of children. ${ }^{4}$ as far as possible be avoided from the criminal justice process. Based on these thoughts, a concept called diversion was born, which in Indonesian terms is called diversion. ${ }^{5}$

The transfer of the juvenile criminal justice process to keep the criminal justice system from hurting harming the child. such as labeling as a result of a guilty statement or conviction. the purpose of this diversion is to reduce the number of children who are arrested, detained and imprisoned and eliminate the evil stigma / stamp and return the child to the community.

Implementation of diversion is motivated by the desire to avoid negative effects on the soul and development of children by their involvement with the criminal justice

3 M. Nasir Djamil, Children Not To Be Punished (note on the discussion of the Child Justice System Law (UU-SPPA), Sinar Grafika, Jakarta, 2013, P.2.

4 DS Dewi Fatahilla and A.s grateful, Penal Mediation: the application of restorative justice in Indonesian juvenile court, Indie Pre Publishing, Depok, 2011, P.13.

5 Marlina, Introduction to the concept of diversion and restorative justice in criminal law, USU Press. Medan, 2010, P.1. system. This diversion or diversion idea is the best solution that can be used as a formula in the settlement of several cases involving children as criminals. With a non-policy policy step for child offenders, the handling of which is diverted outside the path of the juvenile criminal justice system, through short-term coaching or other methods that are civil or administrative. ${ }^{6}$

Diversi gets a positive response from the Government. The government has the power to make and apply laws as well as legislators, in the case of the juvenile criminal justice system. So that the House of Representatives, which functions as a legislative body, gave birth to Law number 11 of 2012 concerning the Juvenile Justice System instead of law number 3 of 1997 concerning juvenile justice, which was legally passed on July 3, 2012. Legislation products The child justice system is a step forward because the rights of children facing the law are more secure. Where the law of the juvenile criminal justice system upholds restorative justice.

From this, the implementation of diversion has been carried out with the concept of restorative justice in which the settlement involves victims and perpetrators as well as the parties involved in the implementation. Related to crimes committed by minors, we all agree that the perpetrators must still be processed by following with applicable law, by following the principle of equality before the law, but if you look at the framework of child protection it would be unwise if the treatment of minors is equal to treatment of adults because

6 Kusno Adi, Criminal Kebikan in handling narcotics crime by children, UMM press, Malang, 2009, P. 58-59 
physically and psychologically, the condition of children is still unstable compared to adults. The problem is that if children are in prison, the rights guaranteed by the Child Protection Act are unlikely to be fulfilled. Furthermore, the juvenile criminal justice process has a negative impact in the form of evil stigma which can magnify deviant behavior and can shape criminal character making it difficult for children to return to society.

\section{B. DISCUSSION}

\section{Principles of Child Protection Related to Diversity Provisions}

Indonesia itself as a country that has ratified the Convention on the Rights of the Child through Presidential Decree Number 36 of 1990 dated August 25, 1990, has further integrated children's rights into national law, namely into Law Number 23 of 2002 concerning Child Protection.

The Convention on the Rights of the Child regulates children's rights in detail. The focus of the problem of this thesis is regarding the arrangements in the Juvenile Justice System relating to diversion. In the Convention on the Rights of the Child, it is intended to protect the principles of child protection, especially in Article 40, that the Convention on the Rights of the Child does not specifically provide for diversion, but Article 40 emphasizes the possibility of the settlement of children carried out outside the trial lines set out in Article 40 paragraph 3 letters b.

Article 40 paragraph 3 letter $b$ of the child convention can provide opportunities in the settlement of naughty children without having to go through a legal process as long as human rights and legal safeguards are fully respected. $^{7}$ Paragraph 3 letter b with the provisions on the settlement of juvenile cases outside the formal justice route by looking at the best interests of the child.

The policy actions are referred to as diversion as stated in rules 11 and 17.14 of the SMRJJ / The Beijing Rules. The diversion act is a mechanism that allows in handling or solving the problem of child offenders by not taking the formal path in the judicial process towards other social service processes. The application of diversion at all these levels will greatly reduce the negative impact of children's involvement in the justice process. $^{8}$

The provisions in the Beijing Rules that in the criminal justice system for children must prioritize the best interests of the welfare of children and guarantee their rights and children should be kept as far away from the criminal justice system as possible. Diversified in Law Number 11 of $2012^{9}$ concerning the Criminal Justice System for Children And Principles for Child Protection.
7 Ibid.

8 Setya Wahyudi, Implementation of Diversity Ideas in Reforming the Criminal Justice System for Children in Indonesia, Genta Publishing, Yogyakarta, 2011, P.67.

9 Hyacinthus Galang Prastianusa, Application of Diversion to Solve That Case of Children Conflicting With Law in Yogyakarta State Attorney, Jurnal Atma Jaya University, 2016, P 4. 


\section{a. Principles of Child Protection according to national law}

1) Law Number 23 of 2002 concerning Child Protection

Based on the

Convention on the Rights of the Child $^{10}$ which was later adopted in Law Number 23 of 2002 concerning child protection. There are 4 principles of child protection that are the basis for each country in organizing child protection, including: ${ }^{11}$

a) Non-discrimination

This principle is contained in article 2 of the Convention on the Rights of the Child, It is not a child will suffer / experience discrimination and applies to all children, "regardless of race, color, sex, language, religion, political opinions or other opinions, citizenship, national or social origin, wealth, disability, birth or other status of the parent or legal guardian of the child. it means that there is no difference in giving children's rights.

10 Azwad Rachmat Hambali, Diversions for Children in Conflict with The Laws in The Criminal Justice System, Jurnal I/miah Kebijakan Hukum, Vol. 13, No. 1, 2019, P.16.

11 Hadi Supeno, Criminalization of Children Offers Radical Ideas of Juvenile Justice without Criminal Justice, Gramedia Pustaka Utama, Jakarta, 2010, P.53-62 b) The Best Interests of The Child.

This principle is listed in article 3 paragraph (1) of the Convention on the Rights of the Child, which means that if the ruler of a country makes decisions that affect children, the first consideration is that all human beings must be based on the best interests of the child.

c) Right to Life, Survival, and Self-development. This principle is listed in article 6 of the Convention on the Rights of the Child. The article on the right to life includes the formulation of the right to survival and survival of children and the right to develop themselves, which must be guaranteed "to the maximum extent possible". this means that all potential that endangers children must be minimized in the environment around the house, school, and community.

d) Appreciation of Children's Opinions

This principle is stated in article 12 paragraph 1 of the Convention on the Rights of the Child, Children must be 
released to have an opinion on all matters relating to themselves, and every opinion of the child must be considered "according to the age and maturity of the child". that children have the right to be heard and the right to have their opinions taken seriously, including legal or administrative procedures concerned with themselves. In essence, the influence of peers can have an impact on changes in the behavior. ${ }^{12}$

2) Law Number 11 of 2012 concerning the Juvenile Criminal System

Transfer of juvenile
justice processes or
diversion useful to avoid
negative influences of the
proceedings in the next
juvenile justice
administration, for
example, labeling as a
result of a guilty statement
or sentence criminal. ${ }^{13}$
Constitution Number 23 of
2002 concerning Child
Protection which was
amended by Law Number
$35 \quad 2014$ concerning

12 Ida Musofiana, Increasing Children's Consciousness in Motorcycling of Motorcycle on Railway (Study in Demak Regency), Jurnal Pembaharuan Hukum, Vol. 4 No. 3, Dec 2017, P.357.

13 Nurini Aprilianda, Juridical Implications of Diversion Terms in Children's International Instruments in The Law of Children in Indonesia, Jurnal Arena Hukum, Vol.6, No.1, April 2012, P.32
Amendment of Law

Number 23 of 2002 concerning Protection Children and Law Number 11 the year 2012 about the Children's Criminal Justice System all share the principles general child protection ie nondiscrimination, the best interests of the child, survival and growth and development and appreciate the participation child. ${ }^{14}$

The principle of protection of children's rights based on the principles contained in article 2 of the Law on the Criminal Justice System for Children is as follows:

a) Protection

Child protection is intended to protect and nurture children who are dealing with the law including direct and indirect activities from actions that harm children physically and mentally.

b) Justice

Justice is that faithful settlement of the case of the child must reflect a sense of justice for the child. This means that all parties involved in criminal offenses must

14 Ridwan Mansur's opinion was quoted in Nevey Varida Ariani, Implementation of Law Number 11 the year 2012 Regarding the System Juvenile Justice To Protect Children's Interests, Jurnal Media Hukum, Vol. 21, No. 1, 2014, P.108-109. 
avoid and keep

children out of the

judicial process to avoid stigmatization of children in conflict with the law.

c) Non-discrimination Non-

discrimination is the absence of different treatment based on ethnicity, racial religion, class, sex, ethnicity and culture, legal status of children, order of birth of children and physical and / or mental conditions.

d) The best interests of the child.

That is, all actions and decisionmaking concerning children, whether carried out by families, communities or legal stakeholders, the environment and child development and development are always the main consideration.

e) Appreciation of children's opinions.

Respect for the child's opinion is respect for the child's right to participate and express his opinion in decision making, especially when it comes to matters affecting the child's life.

f) Survival and development of children.
Quality

protection for children should have degrees which is at least the same as protection towards adults, because of everyone have the same position in front law (equality before the law). ${ }^{15}$ Child survival and development are the most basic human rights for children protected by the state, government, society, family and parents.

g) Child coaching and nursery.

Children in

Indonesia are getting to know internet at a very young age. Most are starting to get to know the internet on age 6-8 years, but not a few anyway who have started to get to know the internet on younger age. Some even acquainted with the internet at his age only 3 years. Majority of children get to know the internet through deep introductions informal education

environment that is home through parents, siblings and 
even grandmothers.

The most used

location not to access

the internet far differently. Access at home be the most chosen option. ${ }^{16}$

Children prefer

to open websites or website addresses related to interests fun or leisure compared to that relates to academic activities at school. Nevertheless, there are still children who use the internet for academic interests by accessing source of information in the form of e-mail. ${ }^{17}$

Coaching is an activity to improve the quality, unfaithfulness to an almighty god, intellectual attitudes and behavior, skills training, professional and physical and spiritual health of children inside and outside the criminal justice process. Guidance is the provision of guidance to improve the quality of piety to God Almighty, intellectual, attitude and behavior,

16 Puspita Adiyani Candra, Internet Use in School Children Aged 6-12 Years in Surabaya, Jurnal Commonline, Vol.1, No. 2, 2013.

17 Weny Rochmawati, Internet Utilization Behavior (Descriptive Study of the Utilization of the Internet for the Interest of Entertainment and Academic Among Children in the City of Surabaya), Jurnal Libri-Net, Vol. 1, No. 1, 2012, P.12 skills training,

professionalism, as well as physical and spiritual health of prison clients.

h) Proportional. Judicial

proceedings against children often loses its essential meaning, i.e. as a mechanism that must end with efforts to protect interests the best for children (the best interest of the child). Juvenile criminal justice is often constituted the only oriented process formal and not law enforcement oriented to the interests of children. ${ }^{18}$

Proportional

namely all treatment of children must pay attention to the limits of the needs, age, and condition of the child.

i) Deprivation of liberty and punishment as a last resort.

That is children are not deprived of their independence, unless forced to for the benefit of the settlement of the case.

j) Retaliation avoidance. Retaliation

avoidance is the principle of alienating

18 Achmad Ratomi, Concept of Procedure Implementation of Diversity at the Investigation Stage In Settlement of Criminal Acts Conducted by Children, Journal of Legal Arena, Vol.6, No.3, December 2013, P.395 


\author{
retaliation in the \\ criminal justice \\ process.
}

The principle in Law number 23 of 2002 concerning child protection is the adoption of an internationally regulated child rights convention, while the Child Criminal Justice System Law further elaborates on the principles of child protection for children in conflict with the law become several parts contained in article 2 of the Criminal Justice System for Children. The focus of this paper is to use the principles contained in the Child Protection Act, because the perspective of child protection is a way of looking at all issues by placing the child's position as first and foremost. Such a perspective is when always placing the affairs of the child as the most important thing in the best interests of the child.

\section{b. Diversion Provisions in the Law on the Criminal Justice System for Children}

The Child Criminal Justice System Act substantially must be by following international and national instruments that set out the principles and legal norms set forth in the Criminal Justice System for Children. Based on the description above In Article 6 of the Law on the Criminal Justice System the Child regulates the diversion objectives, which are as follows:

a. Achieve peace between victims and children;

b. Resolving cases of children outside the judicial process;

c. Avoiding children from deprivation of independence;

d. Encourage people to participate; and

e. Immerse a sense of responsibility to the child.

The five objectives of the Criminal Justice System for Children in Article 6 are only to prioritize the welfare approach for children and the best interests of children. This is by following the principles of protection contained in the principles of the Criminal Justice System for Children and the principles contained in Law number 2 of 2002 concerning Child Protection that all actions and decision-making concerning children, must prioritize the welfare of children, whether done by family, community or legal stakeholders, the survival and development of children is always a major consideration. ${ }^{19}$

Requirements for diversion are not in line with the principle of the Convention on the Rights of the Child or decisions must be made in the best interest of the child, if there is a desire of consent from the victim, then weakens

19 Ach. Alif, Juridical Analysis of Diversion Provisions in Law Number 11 Of 2012 Concerning Children Criminal Justice Systems in The Protection of Children Rights, Jurnal Fakultas Hukum Brawijaya University, 2013, P.13-14 
the principle of legal certainty and undermines the principle equality before the law, which if it depends on the will of the victim allows the diversion process will not be carried out which ultimately the child must undergo a formal justice process.

\section{Relationship of Diversity and Restorative Justice}

Diversity and Restorative Justice are the basis for legal reform in the implementation of the juvenile criminal justice system, which can be seen in Law Number 11 of 2012 concerning the Juvenile Criminal System, which aims to prevent child offenders from punishment or punishment. The provision of diversion and restorative justice in its implementation involves a third party in resolving problems between the child who committed it and the child who was a victim in the crime, involving each of their families, as well as other parties, with the aim of the case settlement process being pursued so that the child the perpetrators of criminal offenses are far from the criminal process against the offenders.

This provision is by following the Convention on the Rights of the Child and the Beijing rules which emphasize that efforts are diversified in the juvenile justice system. This is useful to keep away from settlement with the juvenile criminal justice system which tends to hurt child development.

$$
\text { Restorative justice }
$$
approaches provide opportunities and possibilities for victims of crime to obtain reparations, a sense of security, enable actors to understand the causes and consequences of their behavior and take responsibility in a meaningful way and enable communities to understand the main causes of crime, to advance the welfare of the community and prevent crime. Restorative justice presents a series of flexible actions that can be adapted to the existing criminal justice system and are complemented by taking into account legal, social and cultural conditions. The use of restorative justice will not prejudice the right of the state to prosecute suspected criminal acts. ${ }^{20}$

Therefore, restorative justice or consensus-based justice or justice is a Diversi process, where all parties involved in a criminal offense must jointly overcome the problem and create an obligation to make things better by involving victims, children and the community in finding a solution to improve, reconcile, and reassure that is not based on retaliation. ${ }^{21}$

$\begin{array}{ccc}\text { Restorative justice } & \text { or } \\ \text { consensus-based } & \text { justice in }\end{array}$
Indonesian indigenous peoples has become a tradition among others in the Papuan, Aceh, Bali, West Sumatra, and Lampung traditional law. As in Bali through the Pakraman traditional village which is applied which is another dimension identical to the settlement of cases outside the court through the mediation of penalties. ${ }^{22}$

20 Muladi, Restorative Justice in the Criminal Justice System and Its Implementation in the Settlement of Criminal Acts committed by Children, BPHN, Jakarta, 2013, P.14.

21 Lilik Mulyadi, Criminal Justice System for Children, Alumni, Bandung, 2014, P.163.

22 Ibid.. 
The problem is that the legitimacy of adat justice was abolished in 1950 through the 1951 Emergency Law. Mediation of punishment is an alternative form of dispute resolution outside the court (Alternative Dispute Resolution/ADR). Relatively, the Restorative Justice approach before the enactment of Law Number 11 of 2012 in the process of settling cases of the crime of Children, Restorative Justice has been regulated in Article 45 through Article 47 of the Criminal Code although not explicitly regulated. Article 45 states: In the case of criminal prosecution of persons who have not yet matured for committing acts before the age of 16 , the judge may determine: a) order that the guilty be returned to his parents, guardians or their carers without any crime; or b) order that the guilty be handed over to the government without any criminal if the act is a crime or one of the violations based on articles 489, 490,492, 496, 497,503-505, $514,517,519,526,531,532,536$ and 540 and it has not yet passed two years since it was found guilty of a crime or one of the violations above and the verdict has become permanent; impose penalties on the guilty.

The settlement of the criminal act of the child through mediation was carried out before the birth of the Law on the Criminal Justice System for Children but does not explicitly regulate restorative justice. Likewise, the police as law enforcement officers based on article 18 of Law Number 2 of 2002 concerning the Police, are determined (1) For the public interest of the Republic of Indonesia state police officers in carrying out their duties and authorities, they can act according to their judgment. (2) The implementation of the provisions referred to in paragraph (1) can only be carried out in a very necessary condition by observing the laws and regulations, as well as the code of ethics of the police profession. The explanation of article 18 paragraph (1) is meant by "acting according to his judgment" The implementation of this provision is known as police discretion.

Then with the birth of the Law on the Child Criminal Justice System restorative justice and diversion are regulated in a strictly, namely in more detail the diversion is regulated in Chapter II articles 6 through Article 15 of Law Number 11 of 2012 and the procedures and stages of diversion are regulated in the Supreme Court Regulations Republic of Indonesia Number 4 of 2014 concerning Guidelines for Implementing Diversity in the Criminal Justice System for Children. Diversion aims (Article 6 paragraphs (1 \& 2)) to 1) achieve peace between victims and children, 2) resolve cases of children outside the judicial process, 3) prevent children from deprivation of liberty, 4) encourage people to participate, and 5) instill a sense of responsibility to the child. At the level of investigation, prosecution, and examination of cases of children in the district court must be pursued Diversi. Diversion is carried out if a crime is committed (Article 7 paragraphs (1 \& 2): 1) threatened with imprisonment of less than 7 (seven) years (article 7 paragraph (2) letters a) and 2) does not constitute a repeat of the criminal act (article 7 paragraph (2) letter b). The diversion process (article 8 ) is 
carried out through deliberations involving children and their parents/guardians, victims and/or guardian parents, social advisers, and professional social workers based on a restorative justice approach (article 8 paragraph (1)) in case it is needed, deliberation can involve social welfare workers, and/or the community (article, 8 paragraph (2)). The diversion process must pay attention to : 1 ) the interests of the victim; 2) children's welfare and responsibilities; 3). avoidance of negative stigma; 4). or LPKS no later than 3 (three) months; or 4) retaliation avoidance; 5.) community harmony; and 6) propriety, decency, and public order. In carrying out the diversion of investigators, public prosecutors, and judges must consider (articles 9 $(1 \& 2): 1)$ categories of criminal acts (Article 9 (1) letter a), 2) the age of the child (Article 9 paragraph (1) letter b), 3) results of community research from BAPA; and 4) support of family and community environment.

Continuing diversity agreement (agreement between parties involving children and parents/guardians, victims and/or parents/guardians, community counselors, professional social workers, representatives and other parties involved) to resolve criminal offenses in the form of violations, minor criminal offenses, criminal offenses without victims, or the value of the loss of the victim not more than the value of the minimum wage of the local province as referred to in article 9 paragraph (2) above can be carried out by the investigator together with the offender and/or his family, social counselor, and can involve community leaders.

The diversion agreement is carried out by the investigator on the recommendation of the social adviser to take the form (Article 10 paragraph (1 \& 2): 1) to recover damages in the event of a victim; 2 ) medical and psychosocial rehabilitation; 3) Submission back to parents/guardians; 4) participation in education or training in educational institutions or LPKS (Social Welfare Organization) for a maximum of 3 (three) months; or 5) community service for a maximum of 3 (three) months. Forms of an agreement are diversified, including (article 11): 1) peace with or without compensation; 2) submission back to parents/guardians; 3) participation in education or training in educational institutions or victims and witness protection agencies no later than 3 (three) months; or 4) community servants.

The juvenile criminal justice process is continued in case (Article 13): a. the diversion process did not produce an agreement; or $b$. the diversion agreement was not implemented. Article 14 (1) oversight of the diversion process and implementation of the agreements resulting from the direct supervisor of the official responsible at each level of examination. (2) as long as the diversion process takes place until the diversion agreement is implemented, the social adviser is required to provide assistance, guidance, and supervision. (3) if the agreement on diversion is not carried out within the stipulated time, the social adviser immediately reports it to the responsible official 
as referred to in paragraph (1). (4) The responsible official as referred to in paragraph (3) must follow up the report within a maximum period of 7 (seven) days. Thus the existence of this Law will prevent children from treatment that can harm the development of children who are dealing with the law or the criminal justice system of children. Therefore, future criminal acts of children can be resolved not brought to the criminal court, but resolved in a restorative court where problems are resolved jointly between visible children, family, and other relevant parties facilitated by officers who are oriented towards child protection. In addition to supporting the existence of restorative justice as a form of resolution of the crime of the child, the requirements of the restorative justice approach are needed, namely: $:^{23}$

a) In handling cases of children as perpetrators of crime, it should always pay attention to the age of the offender, the younger the age of the offender the more important it is to settle using the restorative justice approach. The settlement with the restorative justice approach will be effective if the child recognizes the act and regrets it. The Settlement with a restorative justice approach must consider the condition of the child when committing a crime. If the motivating factor for a child to commit a crime is beyond the control of the child

23 Yul Ernis, Diversion and Restorative Justice in Case Settlement of Juvenile Justice System in Indonesia, Jurnal IImiah Kebijakan Hukum, Vol 10. No. 2, 2016, P.171 and or the child commits a crime for the first time, then the settlement with the restorative justice approach is carried out using means of family mediation or deliberation, involving the victim, the perpetrator and his family a top priority.

b) Criminal cases involving children as perpetrators must be sought through a restorative justice approach. When completing cases of criminal acts committed by children, consideration should be given to the priority of criminal acts and the number of criminal acts that have been committed.

c) Losses suffered by victims due to criminal acts can be physical, psychological, material and social which can have a serious impact on victims, then the victim's consent is needed in the settlement of the case of the child.

d) In handling cases of child perpetrators of criminal offenses the support of parents/guardians and families is very important so that the restorative justice approach can be successful. The parent/guardian or family of the child needs to be actively involved in the resolution of the case.

e) Types of handling with the restorative justice approach :

1) Mediating the victim with the perpetrator to settle the dispute through the negotiation process in to obtain the agreement of the parties with the assistance of one or more mediators. (Article 1 point 6 
and point 7 of the Supreme Court regulations of the Republic of Indonesia Number 1 of 2008).

2) Musyawarah family to settle children's cases through deliberations involving the perpetrators 'families and victims' families, facilitated by a facilitator from a neutral party to obtain an agreement from both parties.

3) Community deliberations to settle children's cases through deliberations involving the perpetrators 'families, victims' families and community / religious leaders, facilitated by a facilitator from a neutral party to obtain agreement from both parties.

f) Mechanisms for handling with restorative justice approaches :

1) Investigators, public prosecutors, and judges in resolving the case of children with a restorative justice approach must consider: categories of crime, age of the child, the results of community research from the community hall, and family and community environmental support.

2) The stages in deliberations: the stage of information gathering, the consideration of family prices, negotiations, and agreements.
The results of the restorative justice agreement will produce several alternatives including : $:^{24}$

a) Peace with or without compensation;

b) Submission back to parents / guardians;

c) Participation in education or training to educational institutions, social welfare implementing institutions or social welfare institutions; or community service. Restorative justice decisions included in a child's case file must be considered by prosecutors when making demands and by judges when making decisions. The case register of children with the completion of a restorative justice approach to the police, prosecutors, courts, and correctional institutions was made specifically.

\section{CONCLUSION}

Diversion is a settlement of cases of children that are carried out outside formal justice with the aim of preventing children from stigmatizing children who are dealing with the law must be in accordance with the purpose of diversion in The Beijing Rules. The diversion provisions in the Child Criminal Justice System Law do not yet reflect the principle of child protection as mandated by the Child Protection Act and the Child Criminal Justice System Law. Where the diversion in the Law on the Criminal Justice System for Children has not fully mandated the principle of the

24 Yul Ernis, Diversion and Restorative Justice in Case Settlement of Juvenile Justice System in Indonesia, Jurnal IImiah Kebijakan Hukum, Vol 10. No. 2, 2016, P.172 
best interests of children from the perspective of child protection, with a perspective on all issues by placing the child first and foremost.

The Restorative Justice Approach in the settlement of cases of criminal acts of children has an important meaning in the Juvenile Justice System and is the basis in the current Draft Law on the Criminal Law which, among other things, changes the paradigm of the goals of conflict resolution to be caused by criminal acts, restoring balance and bring about a sense of community peace and a spirit of concern for victims of crime. Restorative justice or justice or deliberation based deliberation is a process of diversification, that is, all parties involved in a criminal offense certainly jointly resolve the problem and create an obligation to make things better by involving victims, children and the community in seeking a solution to repair, reconcile, and reassure that is not based on retaliation.

\section{BLIBIOGRAPHY}

\section{Book:}

Ach. Alif, 2013, Juridical Analysis of Diversion Provisions in Law Number 11 Of 2012 Concerning Children Criminal Justice Systems in The Protection of Children Rights, Jurnal Fakultas Hukum Brawijaya University, Malang;

Achmad Ratomi, Concept of Procedure Implementation of Diversity at the Investigation Stage In Settlement of Criminal Acts Conducted by Children, Journal of Legal Arena, Vol.6, No.3, December 2013;

Azwad Rachmat Hambali, Diversions for Children in Conflict with The Laws in The Criminal Justice System, Jurnal Ilmiah Kebijakan Hukum, Vol. 13, No. 1. 2019;

DS Dewi Fatahilla and A.s grateful, 2011, Penal Mediation: the application of restorative justice in Indonesian juvenile court, Indie Pre Publishing, Depok;

Hadi Supeno, 2010, Criminalization of Children Offers Radical Ideas of Juvenile Justice without Criminal Justice, Gramedia Pustaka Utama, Jakarta;

Hyacinthus Galang Prastianusa, 2016, Application of Diversion to Solve That Case of Children Conflicting With Law in Yogyakarta State Attorney, Jurnal Atma Jaya University, Yogyakarta;

Ida Musofiana, Increasing Children's Consciousness in Motorcycling of Motorcycle on Railway (Study in Demak Regency), Jurnal Pembaharuan Hukum, Vol. 4 No. 3, Dec 2017;

Kusno Adi, 2009, Criminal Kebikan in handling narcotics crime by children, UMM press, Malang;

Lilik Mulyadi, 2014, Criminal Justice System for Children, Alumni, Bandung;

M. Nasir Djamil, 2013, Children Not To Be Punished (note on the discussion of the Child Justice System Law (UU-SPPA), Sinar Grafika, Jakarta; 
Marlina, 2010, Introduction to the concept of diversion and restorative justice in criminal law, USU Press. Medan;

Muladi, 2013, Restorative Justice in the Criminal Justice System and Its Implementation in the Settlement of Criminal Acts committed by Children, BPHN, Jakarta;

Nashriana, 2011, Legal protection for children in Indonesia, Raja grafindo Persada, Jakarta;

Novi Edyanto, Restorative Justice To Resolve Cases Children Confronting the Law, Jurnal Ilmu Kepolisian, Vol 11, Nomor 3, Dec 2017;

Nurini Aprilianda, Juridical Implications of Diversion Terms in Children's International Instruments in The Law of Children in Indonesia, Jurnal Arena Hukum, Vol.6, No.1, April 2012;

Puspita Adiyani Candra, Internet Use in School Children Aged 6-12 Years in Surabaya, Jurnal Commonline, Vol.1, No. 2, 2013.

Ridwan Mansur's opinion was quoted in Nevey Varida Ariani, Implementation of Law Number 11 the year 2012 Regarding the System Juvenile Justice To Protect Children's Interests, Jurnal Media Hukum, Vol. 21, No. 1, 2014, P.108-109.

Setya Wahyudi, 2011, Implementation of Diversity Ideas in Reforming the Criminal Justice System for Children in Indonesia, Genta Publishing, Yogyakarta;

Syamsu Haling, Paisal Halim, Syamsiah Badruddin, \& Hardianto Djanggih, Protection of the Rights of Street Children In the Field of Education According to Law National and International Conventions, Journals Law \& Development, Vol.48, No.2, April June 2018;

Weny Rochmawati, Internet Utilization Behavior (Descriptive Study of the Utilization of the Internet for the Interest of Entertainment and Academic Among Children in the City of Surabaya), Jurnal Libri-Net, Vol. 1, No. 1, 2012, P.12

Yul Ernis, Diversion and Restorative Justice in Case Settlement of Juvenile Justice System in Indonesia, Jurnal Ilmiah Kebijakan Hukum, Vol 10. No. 2, 2016; 